\title{
MULTINATIONAL SECURITIES \\ OFFERINGS: A CANADIAN \\ PERSPECTIVE
}

\author{
Mark Q. ConNelly*
}

I

\section{INTRODUCTION}

In the spring of 1985, the Securities and Exchange Commission (SEC) published requests for public comment on two companion "concept releases," more commonly known as "trial balloons," concerning the internationalization of securities markets. The first release, ${ }^{1}$ promulgated pursuant to the Securities Act of 1933, ${ }^{2}$ sought comments on two alternative prospectus approaches to facilitate multinational securities offerings: the "reciprocal approach" and the "common prospectus" approach. ${ }^{3}$ The second release, ${ }^{4}$ promulgated pursuant to the Securities Exchange Act of $1934,{ }^{5}$ sought comments on various issues arising from the increased internationalization of the secondary securities markets.

In discussing the Canadian perspective on multinational securities offerings, this article focuses more on the SEC's 1933 Act Release than the 1934 Act Release. Certain areas regulated by the 1934 Act and discussed extensively in the 1934 Act Release, such as the consolidation reports of trading volume and prices among various geographically dispersed trading markets, are beyond the scope of this article. These areas are highly technical and do not directly affect the securities issuer. However, those aspects of the 1934 Act which affect primary distributions, such as continuous reporting requirements, will be discussed.

The subject of internationalization of the primary issue securities markets has probably become more topical recently for Canadians as a result of the great liberalization by the government of Ontario of the rules respecting

Copyright $\odot 1988$ by Law and Contemporary Problems

* Member of the bars of Ontario, New York, and the District of Columbia; partner, Davies, Ward \& Beck, Toronto.

1. Facilitation of Multinational Securities Offerings, Request for Public Comment, Securities Act Release No. 33-6568, 50 Fed. Reg. 9,281 (Mar. 7, 1985) [hereinafter 1933 Act Release].

2. 15 U.S.C. $\$ 77$ (1982).

3. See infra notes 64 \& 65 and accompanying text for an explanation of the SEC's two approaches.

4. Request for Comments on Issues Concerning Internationalization of the World Securities Markets, Exchange Act Release No. 34-2 1958, 50 Fed. Reg. 16,302 (Apr. 25, 1985) [hereinafter 1934 Act Release].

5. 15 U.S.C. $\& 78 \mathrm{a}(1982)$. 
foreign ownership of securities dealers. ${ }^{6}$ While the ownership of dealers is obviously a topic distinct from prospectus requirements, it would not be surprising if eventually greater internationalization in the former area contributed to the same phenomenon in the latter.

\section{II}

\section{Internationalization of Securities Markets}

The statistics on the internationalization of securities markets are impressive. It is estimated that in 1985 there were 328 corporations with an active international market-meaning at least one liquid market outside the home country - for their equity securities. ${ }^{7}$ United States private issuers offered $\$ 3.5$ billion (U.S.) in debt securities in the Eurobond market during the first nine months of $1986 .{ }^{8}$ In secondary trading markets, transactions by foreign investors in U.S. equities had a value in the first half of 1986 of approximately $\$ 131$ billion (U.S.) and transactions in foreign equities by U.S. investors during the same period had a value of approximately $\$ 45$ billion (U.S.) ${ }^{9}$ At the beginning of 1984 , there were forty-six foreign securities or American Depository Receipts listed on the New York Stock Exchange, fiftytwo on the American Stock Exchange (accounting for $12.8 \%$ by value of the transactions on the AMEX in that year), and 294 quoted on NASDAQ. ${ }^{10}$

The statistics on the internationalization of the Canadian securities markets, although naturally much smaller in absolute terms, are also impressive. During the first half of $1985,26 \%$ by value of the total new issues of debt securities by Canadian governmental and private issuers, or $\$ 4.9$ billion (U.S.) worth of debt, was issued outside of North America. ${ }^{11}$ The Canadian share of the Eurobond market is believed to be over $10 \% .^{12}$ Between $7 \%$ and $10 \%$ of new equity issues by Canadian companies are placed outside Canada on an annual basis. ${ }^{13}$ As early as 1984 , the dollar value of trades in securities interlisted among The Toronto Exchange, other Canadian

6. Regulation to Amend Regulation 910 of Revised Regulations of Ontario, 1980 (June 17, 1987). As a result of the revisions, non-Canadians are permitted, as of June 30,1987 , to own up to $50 \%$ of the voting and participating securities of a securities dealer licensed in Ontario, and restrictions on foreign ownership will be removed completely on June 20, 1988. For a description of the formerly, extremely restrictive rules governing foreign ownership of securities dealers, see Connelly, The Licensing of Securities Market Actors, in 3 Proposals for a Securities Market Law for Canada 1265, 1385-92 (P. Anisman ed. 1979).

7. Response of The Toronto Stock Exchange to Request for Comments on Issues Concerning Internationalization of the World Securities Markets, S.E.C. File No. 37-16-85, at 4 n.3 (July 7, 1985) [hereinafter TSE Response to 1934 Act Release].

8. Finance Officers' 'Wider Role, N.Y. Times, Oct. 20, 1986, at 23, col. 3.

9. Ketchum, Internationalization of the Securities Markets, in InTERnational Securities Markets 13 (Practicing Law Institute 1987).

10. 1934 Act Release, supra note 4 , at 16,303 .

11. Submission of the Staff of the Ontario Securities Commission to the Securities and Exchange Commission Concerning the Facilitation of Multinational Securities Offerings, S.E.C. Release No. 33-6568, at 1-222 (Oct. 4, 1985), reprinted in 8 ONT. Sec. Commission Bull. 3972,3977 (1985) [hereinafter OSC Response to 1933 Act Release]

12. TSE Response to 1933 Act Release, supra note 7 , at 2 n.2.

13. Id. 
exchanges, and U.S. exchanges was $\$ 25.2$ billion. ${ }^{14}$ In that year, some seventy Canadian equities were traded on one or more American exchanges or quoted on NASDAQ, and twenty-three were traded on the London Stock Exchange. ${ }^{15}$ The recent establishment of computer assisted trading links between The Toronto Stock Exchange and the American Stock Exchange and between the Montreal Exchange and the Boston Stock Exchange has facilitated increased trading between the United States and Canada. This growing internationalization of the two countries' securities markets will present increasing regulatory concerns.

Although there have been some very large multinational offerings by Canadian issuers, ${ }^{16}$ the chief impetus for the SEC's 1933 Act Release may have been the spate of privatizations carried out by the Government in the United Kingdom. A striking example is the initial public offering by British Telecommunications plc in 1984 which was then the largest initial public offering ever made. ${ }^{17}$

The 1933 Act Release focused on integration of the primary issue market with the United Kingdom and Canada because of the large number of issuers from these countries accessing the U.S. market and the similarity of disclosure requirements among the three countries. ${ }^{18}$ Nonetheless, the problems in coordinating a simultaneous offering in Canada, the United States, and the United Kingdom are far greater than within North America alone. Although the systems for bringing new issues to market in Canada and the United States are nearly identical, the system in the United Kingdom is very different from the North American standard. For example, in the United Kingdom there is no preliminary prospectus, the equivalent of a pricing date is set weeks or months in advance, and there is, as a practical matter, no last minute ability to alter the prospectus offering price. ${ }^{19}$ Additionally, in the United Kingdom, substantial publicity-indeed advertising-is undertaken before the prospectus is published in the newspaper. Moreover, the regulation of new issues is undertaken by the London Stock Exchange in the case of listed companies and otherwise by the Registrar of Companies, rather than by a securities commission. ${ }^{20}$ Finally, the underwriters are prohibited from stabilizing the after-market. This prohibition exposes the North American

14. Id. at 2 .

15. Id. at 2 n. 2 .

16. For example, the 1983 multinational offerings by Bell Canada Enterprises and Alcan Aluminum Limited were qualified for sale in the United States. See Letter from Marc J. Ryan to Michael Melanson (July 5, 1985).

17. The British Telecommunications public offering raised $\$ 269,118,000$ (U.S.). See Prospectus for British Telecommunications (Dec. 3, 1984).

18. 1933 Act Release, supra note 1, at 9,281 .

19. Id. at $9,282-83$.

20. This remains the case even after the effectiveness of the Financial Services Bill in the United Kingdom on October 27, 1986. The Financial Services Bill has entrusted the regulation of persons in the securities business, but not securities issuers (other than mutual funds), to the Securities and Investments Board, a supervisory body financed and staffed by the private sector. See Pimlot, The Reform of Investor Protection in the U.K.-An Examination of the Proposals of the Gouler Report and the $L . K$. Government's White Paper of Januan', 1985, 7 J. Comp. Bus. \& CaP. Market L. 141 , $161-62$ (1985). 
underwriters in an offering by a British corporation to the risk that British speculators will regard foreign stabilization practices as in effect supplying a downside guarantee during the distribution. In recognition of the fundamental disparities between the primary offering regimes of either of the North American countries, on the one hand, and that of the United Kingdom, on the other, this article focuses primarily on the interrelationship between the Canadian and U.S. securities markets.

\section{III}

\section{Current United States Treatment of Foreign Issuers}

For a multinational securities offering possibly to warrant treatment different from any nation's domestic prospectus requirements, it must be an offering made simultaneously in two or more jurisdictions and not simply an offering within a single jurisdiction by a foreign issuer. Assuming a public interest in facilitating the internationalization of primary securities markets, it is hard to imagine any compelling reason why foreign issuers cannot be expected to comply strictly with the host jurisdiction's securities laws. Nevertheless, the SEC has eased the way for foreign issuers by the promulgation in 1982 of Forms F-1, F-2, and F-3.21 As compared with the correspondingly numbered " $S-$ " forms, the "F-" forms offer three advantages to foreign "private issuers" seeking to register offerings under the 1933 Act. ${ }^{22}$ First, financial statements may be prepared in accordance with "a comprehensive body of accounting principles other than those generally accepted in the United States," although a discussion and quantification of the material deviations from U.S. GAAP must be provided. ${ }^{23}$ Second, remuneration paid by the issuer to its officers and directors may in most cases be disclosed on an aggregate, rather than an individual, basis and the amount of disclosure regarding certain transactions in which management has a pecuniary interest has also been limited. ${ }^{24}$ Third, financial statements for foreign private issuers do not have to be quite as current as for U.S. domestic issuers. ${ }^{25}$ The accommodations to foreign issuers represented by the " $F$ " forms for 1933 Act registration are an extension of an accommodation made

21. Adoption of Foreign Issuer Integrated Disclosure System, Securities Act Release No. 33 . 6437, 47 Fed. Reg. 54,764 (Dec. 6, 1982). The forms are reprinted at 2 Fed. Sec. L. Rep. (CCH) 1 6,951-75 (Dec. 4, 1982).

22. The term "foreign private issuer" is defined in Rule 405 under the 1933 Act, 17 C.F.R. $\$ 230.405$ (1986), as a foreign nongovernmental issuer other than one meeting both of the following conditions: (1) more than 50\% of its outstanding voting securities are held by residents of the United States; and (2)(a) the majority of the issuer's executive officers or directors are United States citizens or residents, (b) more than $50 \%$ of the issuer's assets are in the United States, or (c) the issuer's business is administered principally in the United States.

23. See SEC Regulation S-X Rule 4-01(a), 17 C.F.R. \$ 210.4-01 (a) (1986). Rule 4-01 (a) requires a reconciliation to United States accounting principles according to the provisions of Securities and Exchange Commission Form 20-F, Item 18. Id.

24. See Form 20-F, General Instructions, Items 11 and 13, reprinted in 4 Fed. Sec. L. Rep. (CCH) I 29,721 (Dec. 31, 1983) [hereinafter Form 20-F].

25. See SEC Rule 3-19, 17 C.F.R. § 210.3-19 (1986). 
in 1979 by the introduction under the 1934 Act of Form 20-F for registration and annual reports. ${ }^{26}$

Foreign issuers who qualify to use the " $F$ " forms confront less onerous obligations in terms of the form itself and also face a lighter regulatory burden than U.S. domestic (and certain Canadian) issuers who must use the Form 10-K under the 1934 Act and the " $S$ " forms under the 1933 Act. Issuers using the " $F$ " forms are not required to comply with SEC proxy and insider reporting rules and do not have to make quarterly reports. ${ }^{27}$ Furthermore, their insiders are not subject to the infamous section 16(b) of the 1934 Act, requiring disgorgement of "short-swing" securities trading profits. ${ }^{28}$

Some Canadian issuers, however, are not entitled to use the " $F$ " forms. Canadian issuers who either have a class of securities listed on an exchange in the United States or have filed a registration statement under the 1933 Act must, like their U.S. domestic counterparts, use the Form 10-K and the " $S$ " forms. ${ }^{29}$ Nonetheless, all Canadian private issuers, without regard to their entitlement to use the " $F$ " forms, are permitted to file financial statements prepared in accordance with accounting principles generally recognized in Canada. ${ }^{30}$ Furthermore, Canadian issuers, unlike other non-U.S. issuers, qualify for the small offering exemption under Regulation $\mathrm{A}^{31}$ and are permitted to use the simplified disclosure system of Form S-18 for small offerings. ${ }^{32}$ Hence, even without further reform, current SEC regulations provide substantial accommodations to Canadian issuers.

IV

\section{Foreign Issuers in the Canadian Domestic Market}

\section{A. Economic Disincentives}

Several factors render Canadian securities markets less attractive to U.S. issuers (other than mutual funds, whose securities were excluded from the purview of the 1933 Act Release) than the U.S. securities markets are to Canadian issuers. In comparison to the U.S. market, the Canadian market is quite small. Canadian interest rates have consistently exceeded U.S. interest rates for the last ten years, a result in large part of the Canadian government's efforts to support the Canadian dollar. The Canadian income tax system is strongly biased in favor of investments in Canadian, as opposed to foreign, securities. For example, Canadian tax-exempt pension plans and registered

26. Form 20-F was adopted in Securities Exchange Act Release No. 34-16371, 44 Fed. Reg. 70,132 (Dec. 6, 1979).

27. See SEC Rules 3a12-3(b) \& 13a-13, 17 C.F.R. §§ 240.3a12-3(b) \& 240.13a-13(b)(2) (1986).

28. See SEC Rule 3a12-3, 17 C.F.R. \& 240.3a12-3 (1986).

29. Form 20-F, supra note 24, at ๆ 29,721 (Instruction A).

30. See SEC Regulation S-X, Rule 4-01(a)(2), 17 C.F.R. 210.4-01(a)(2) (1986).

31. See SEC Rule 252, 17 C.F.R. 230.252 (1986).

32. See Form S-18, Instruction 1. The form is reprinted at 2 Fed. Sec. L. Rep. (CCH) I 7,301 (Jan. 20, 1987). 
retirement savings plans are subject to a penalty tax of $1 \%$ per month if they have more than $10 \%$ of their portfolios in non-Canadian securities. ${ }^{33}$ Registered retirement savings plans constitute a high proportion of individual savings by Canadians and a large portion of all investments in equities by individual Canadians are for the accounts of their registered retirement savings plans. ${ }^{34}$ Finally, the effective tax rate on dividends is lower for dividends received from Canadian companies than for dividends received from non-Canadian companies. ${ }^{35}$

Non-Canadian issuers proposing to distribute securities within Canada will encounter two important distinctions between the Canadian and U.S. securities regulation schemes. First, securities regulation in Canada is a matter of provincial and not federal responsibility. This distinction constitutes an obstacle, though not insuperable, to Canadian participation in multinational securities offerings. Second, in Ontario, Nova Scotia, Quebec, Alberta, and British Columbia there is a "closed system" of statutory prospectus exemptions and resale rules modeled after Professor Loss's proposals in the American Law Institute Federal Securities Code. ${ }^{36}$ Because, however, the provincial systems provide administrators with broad exemptive powers, this second distinction presents something of an opportunity.

\section{B. A System of Provincial Regulation}

To an extent not yet judicially settled, the Canadian system of provincial securities regulation is constitutionally mandated. The Canadian Constitution reserves to the respective provinces the exclusive power to legislate in relation to "Property and Civil Rights in the Province."37 Moreover, the federal power to make laws governing "The Regulation of Trade and Commerce" 38 has not been interpreted as broadly as the commerce clause of the U.S. Constitution. ${ }^{39}$ The drafters of The British North America Act of $1867^{40}$ sought to draft a charter for a strong federal government that would avoid the dangers of excessive local hegemony demonstrated with cataclysmic effect by the Civil War in the United States. By virtue of judicial interpretation and such historical "imperatives" as the need to preserve Quebec's French heritage, the Canadian provinces have emerged

33. Income Tax Act, ch. 63, 1970-1972 Can. Stat. $\$ 206$, as amended.

34. In addition, individuals may deduct in computing their taxable income up to $\$ 1,000$ of Canadian-source interest and dividends received from Canadian corporations, Income Tax Act, $\$ 110.1$, but this deduction is scheduled for elimination in 1988 and later years. See Minister of Finance, White Paper on Tax Reform (June 18, 1987), reprinted as Special Report No. 797, Can. Tax Rep. (CCH) 170 (1987).

35. Income Tax Act, ch. 63, 1970-1972 Can. Stat. §§ 82(1), 121 , as amended.

36. Federal Securities Code $\S \S 301-304$ (Tent. Draft No. 6, 1977).

37. Constitution Act, $30 \& 31$ Vict., ch. 3 , $\$ 92(13)$ (1867).

38. Id. § $91(2)$

39. See P. Hogg, Constitutional Law of Canada 87 n.29 (2d ed. 1985).

40. The British North America Act, 30 \& 31 Vict., ch. 3, \&91 (1867), continues to be the Canadian Constitution insofar as division of powers is concerned. 
much more powerful in relation to the federal government than have the states of the United States.

Although in the late 1970's there appeared a good chance that a federal scheme of securities regulation might be developed in Canada, ${ }^{41}$ at present the prospects for federal regulation seem remote. Even if constitutional problems could be resolved,42 the provincial securities commissions are solidly entrenched and some degree of provincial regulation would remain under a system of federal securities regulation. ${ }^{43}$ Canadians are not likely to favor a federal system that would merely constitute another layer of regulation super-imposed on the existing system rather than a truly national system for prospectus clearance and uniform continuous disclosure. In addition, the predominance of Toronto as the financial center of the country militates against the development of a system of federal regulation. ${ }^{44}$ Securities dealers, underwriters, and lawyers, as well as The Toronto Stock Exchange, appear to have developed a satisfactory working relationship with the Ontario Securities Commission. Transmutation of the Ontario Securities Commission into the Canadian Securities Commission is likely to be politically unacceptable. Therefore all concerned parties can be expected to resist change and, barring an event that would demonstrate a clear need for federal regulation, Canada will likely continue with its awkward yet workable system of provincial regulation of a national marketplace. ${ }^{45}$ To the extent that the securities markets are becoming internationalized, Canada's provincial regulatory system complicates, but is not fatal to, her participation.

41. See generally 1-3 Department of Consumer and Corporate Affairs, Proposals for a Securities Market Law for Canada (P. Anisman ed. 1979) [hereinafter Proposals].

42. In recent years, the Supreme Court of Canada has occasionally demonstrated a more hospitable attitude toward a federal regulatory power than in the past. See. e.g., Attorney Gen. of Can. v. Canadian Nat'l Transp., [1983] 2 S.C.R. 206, 207-09; Multiple Access Ltd. v. McCutcheon, [1982] 2 S.C.R. 161, 173 (dictum of Dickson, J. relating specifically to possible national securities legislation); In re Agricultural Prod. Mktg. Act, [1978] 2 S.C.R. 1198, 1201 -02; Caloil, Inc. v. Attorney Gen. of Can., [1971] I S.C.R. 543, 550-52. But see Labatt Breweries, Ltd. v. Attorney Gen, of Can., [1980] I S.C.R. 914, 915-16; Domion Stores, Ltd. v. The Queen, [1980] I S.C.R. 844, 845.

43. See, e.g., Howard, Securities Regulation: Structure and Process, in 3 Proposals, supra note 41 , at 1607; Anisman, The Regulation of the Securities Market and the Harmonization of Provincial Lau's, in Harmonization of Business Law in Canada 77 (R. Cuming ed. 1985) [hereinafter Anisman].

44. The status of Toronto as the predominant financial center is not lightly conceded by Montreal. In the summer of 1986, a proposal, apparently backed by the Canadian Federal Government, emerged to make Montreal and Vancouver tax free zones for certain types of international financial transactions but the proposal appears now to be dead. Globe and Mail, Aug. 30, 1986, at B1, cols. 4-5; Globe and Mail, July 6, 1987, at A13, col. 6.

45. To cite but one example of the differences, only five of the provinces (but including the four most populous ones) have the "closed system" of exemptions and resale rules. These are Ontario, Nova Scotia, Quebec, Alberta, and British Columbia. See Securities Act, 8 Ont. Rev. Stat,, ch. 466, $\S 1$ (1)11 (1980) (definition of “distribution"); Securities Act, ch. 11, 1984 N.S. Stat. \& 1(k) (definition of "distribution"); Securities Act, ch. 48, 1982, Que. Stat. $\$ 5$ (definition of "distribution"); Securities Act, ch. S-6.1, 1981 Alta. Stat. $\$ 1($ () (definition of “distribution”); Securities Act, ch. 42, 1987 B.C. Stat. $\$ 1(1)$ (definition of "distribution"). The other five provinces use the familiar litany of prospectus exemptions which require judicial examination of investment intent to determine whether a distribution has been made to the public. This practice permits extensive leakage of unregistered securities into the public marketplace. 
International market participants can adjust to the provincial regulatory system as national ones have done.

\section{Provincial Cooperation}

Although each of the ten Canadian provinces has its own legislation regulating the distribution of securities within its boundaries, in reality, the provincial regulatory system is not as unworkable as first appears. There is substantial cooperation among the securities administrators of the various provinces and there is a considerable tendency in matters of administration, and even legislation, to let Ontario take the lead. Despite the reluctance of Quebec and, increasingly, Alberta to defer to Ontario's lead, Canada has a workable system for coordinated prospectus clearance among the provinces.

The securities administrators of all of the provinces have promulgated a series of policies known as "National Policies." 46 Pursuant to National Policy No. 1, an issuer files an identical preliminary prospectus simultaneously in all of the provinces where the issuer desires to qualify the securities for sale. The issuer names a principal jurisdiction (usually Ontario), and that jurisdiction undertakes to send a first comment letter within ten business days of receipt of the preliminary prospectus and a second comment letter within a further five days. The first comment letter consists of the comments of the principal jurisdiction and the second letter consists of the comments of the remaining jurisdictions. It is rare for provinces other than Ontario, Quebec, Alberta, and British Columbia to comment on prospectuses. Generally, the issuer and its advisors deal only with the principal jurisdiction, which gathers comments from and circulates responses to the remaining jurisdictions. If a point between the issuer and one of the secondary jurisdictions proves difficult to resolve, the issuer will seek the permission of the primary jurisdiction to deal directly with the particular secondary jurisdiction. Where the principal jurisdiction is Ontario, a need to deal directly with a secondary jurisdiction would generally arise, if at all, only in the cases of Quebec and, to a lesser extent, Alberta.

To be qualified in Quebec, a prospectus must be in the French language, and the French version will be the official version for all Quebec purposes. So long as there exists a French language version, an English language version of the prospectus may be distributed in the province as well.47 Because translation represents a considerable additional cost, some issuers have attempted to forego Quebec qualification of their offerings and to sell in Quebec through prospectus exemptions simultaneously with the prospectus offering elsewhere in Canada. Not surprisingly, the Quebec Securities

46. The National Policies are reprinted at 3 Can. Sec. L. Rep. (CCH) 470-001 (1987).

47. The French language version is the official version and it is probable that if there is a material misstatement in the English language version not present in the French language version, a purchaser in Quebec who was misled by the English language version would not be able to avail himself of the statutory remedies for a false prospectus. Securities Act, ch. 48, 1982 Que. Stat. \$ 40.1; Charter of the French Language, Que. Rev. Stat., ch. C-11 (1977). 
Commission looks with disfavor upon this practice and has threatened denial of prospectus exemptions to issuers and disciplinary proceedings against securities dealers who are parties to it. ${ }^{48}$

Opinions differ on the degree to which National Policy No. 1 has accelerated the prospectus clearance process. Nevertheless, the fact remains that prospectuses do not require an unduly long period to go from preliminary to final on a nationwide basis. Most long form prospectuses require five to six weeks; short form prospectuses normally require a week to ten days.

\section{Hospitable Exemptions}

The broad exemptive powers possessed by the provincial securities administrators have enabled meaningful accomodations to be reached with foreign issuers and underwriters. Accommodations by provincial administrators have included: exemptions to prospectus requirements; waivers of the normal requirement that a private placement offering memorandum include contractual rights of action analogous to the civil liability provisions governing prospectus; and generous administrative interpretations which exempt some foreign issuers from the literal requirements of the statutory closed system.

Recently, numerous European companies have made multinational offerings of securities in Canada by resorting to prospectus exemptions. ${ }^{49}$ Among the most important of the transaction-based prospectus exemptions are those available where the purchaser is either (1) a financial institution, (2) an institution designated by the securities commissions as an "exempt purchaser," or (3) an individual or institution which purchases as principal where the securities have an acquisition cost of not less than $\$ 150,000 .^{50}$

Although these transaction-based exemptions have enabled the Canadian portions of certain multinational offerings to be placed without a Canadian prospectus being qualified, the Canadian underwriters have used the European prospectus as a selling document in Canada. Generally, the regulations governing sales of securities without a prospectus require that if an offering memorandum describing the issuer's business and affairs is used in a private placement, the offering memorandum must describe rights of action in favor of purchasers similar to those that would exist in a distribution by means of a prospectus. Such rights must then be granted to the purchasers by way of the subscription agreement. Therefore, if the offering

48. See Anisman, supra note 43 , at 105 .

49. Shares of Britoil, Cable and Wireless, KLM Royal Dutch Airlines, and Swiss Bank Corporation, among others, have been distributed in Canada in this way.

50. Securities Act, 8 ONt. Rev. Stat. ch. 466, \& 71 (1)(a), (c), (d) (1980). Private placements to exempt institutions, unlike to individuals, are not subject to minimum dollar limits. 
memorandum or prospectus is materially false or misleading, purchasers are entitled to rescission or damages. ${ }^{51}$

Because some foreign offerors have been unwilling to distribute their securities in Canada if they would be subjected to contractual rights of action, the Ontario Securities Commission (OSC) has exempted certain foreign issuers from this requirement. ${ }^{52}$ The OSC has accepted arguments that there was little need for a contractual right of action when the offerees were sophisticated, the issuers were well-known and stable, and a prospectus-type document was being distributed to the purchaser.

None of the three justifications for the waiver of contractual rights of action is conceptually satisfactory. Sophistication of the offerees is not a compelling justification because the prospectus exemptions require that the recipients of offering memoranda be sophisticated, at least to the extent that sophistication accompanies the ability to invest $\$ 150,000$, regardless of whether the memoranda contain contractual rights of action. The Canadian investment dealers who applied for the orders did not undertake to limit solicitations to a peculiarly sophisticated subset of private offerees. To the extent the sophistication of the offerees suggests that there should be no contractual right of action, the basic requirement that such a remedy be available may be misguided. To the extent that exempting the orders was based on the size and reputation of the issuers, the requirement that the offering memorandum contain contractual rights of action may be too broad in failing to distinguish senior from junior issuers. Finally, that the purchasers receive a prospectus-type document should be irrelevant because, had the purchasers received a statutory prospectus, they would have statutory rights of action for rescission or damages for a misleading prospectus. The predominant policy implicit in granting waivers from the requirement of contractual rights of action seems to be the OSC's desire that Canadian dealers and investors should be able to participate in multinational offerings.

In addition to liberalizing the rules governing original distribution, the OSC has also made accommodations for related secondary distributions. Under Canada's closed system, resales of securities (other than exempt securities) distributed without a prospectus may be made only if a specific statutory exemption is available or holding periods have been observed and the issuer is a "reporting issuer," that is, an issuer subject to and in compliance with continuous disclosure obligations aimed at the secondary markets. ${ }^{53}$ Because the Ontario Securities Act limits the great majority of

51. Regulations under the Ontario Securities Act, Regulation 910, ONT. Rev. Reg. \$ 21 (1980). The civil liability consequences of a false prospectus are set out in Securities Act, 8 ONT. REV. STAT. ch. $466, \S 126$ (1980).

52. Britoil, 8 Ont. Sec. Commission Bull. 2944 (1985); Swiss Bank Corporation, 8 ONT. Sec. Commission Bull. 4507 (1985); Cable and Wireless, 9 Ont. Sec. Commission Bull. 371 (1986); KLM Royal Dutch Airlines, 9 Ont. Sec. Commission Bull. 2280 (1986); AB Electrolux, 9 ONT. SEC. Commission Bull. 3387 (1986); National Australia Bank Limited, 10 ONT. Sec. Commission Bull. 2205 (1987); Philips N.V., 10 Ont. Sec. Commission Bull. 3288 (1987).

53. Securities Act, 8 Ont. Rev. Stat. ch. 466, $\$ 71(4)$, (5), (7) (1980). 
transaction-based exemptions to sales by the issuer, for nonreporting issuers the permissible scope of resales is effectively restricted to trades among financial institutions. Conceptually, this is similar to Rule 144 under the 1933 Act, except that the Canadian rules are intended to be exhaustive rather than safe harbor rules. 54

Early in 1986, the OSC effectively ruled that shares of Britoil plc (previously distributed under an exemption from the contractual right of action) could be resold freely notwithstanding that Britoil is not a reporting issuer in Ontario. ${ }^{55}$ The OSC justified this exemption by noting that Britoil is subject to fairly extensive continuous disclosure obligations by virtue of its listing on the London Stock Exchange.

The absence of a permissive, Britoil-type resale ruling in a private placement to the initial Canadian purchasers of securities of foreign nonreporting issuers acquired through a transactional prospectus exemption does not necessarily preclude resale. ${ }^{56}$ Where the securities have a liquid market outside Canada, the Canadian purchaser could privately resell the securities to a non-Canadian financial institution. That institution could then sell them, for example, on the London Stock Exchange. Having no nexus with Ontario, the sale on the London Stock Exchange would be beyond the reach of the Ontario Securities Act. The securities might find their way back to Canada, but so long as the original Canadian purchasers had not in effect orchestrated their return, the securities would be completely and lawfully outside the closed system upon their return.

As is apparent from the preceding discussion, the OSC has power to exempt persons from the prospectus and other provisions of the Ontario Securities Act on an ad hoc basis "where it is satisfied that to do so would not be prejudicial to the public interest." 57 Even though the SEC no-action letter may go some distance in the same direction, the breadth of the OSC's power is markedly greater than the SEC's administrative powers. If the OSC continues to be generally hospitable to multinational offerings, the breadth of its exemptive power presents a real opportunity to issuers and underwriters.

\section{$\mathrm{V}$}

\section{Canadian Issuers in the U.S. Domestic Market}

\section{A. Canadian Law Presents Illusory Barriers}

It should be observed initially that Canadian domestic ownership laws, outside of certain specific industries such as banking and communications,

54. Cf. 17 C.F.R. $\$ 230.144$ (1986).

55. Britoil, 9 Ont. Sec. Commission Bull. 1887 (1986).

56. The author is not aware of other resale rulings comparable to Britoil, and it is doubtful, however, that the Ontario Securities Commission regards itself bound by precedent to the same degree as a court. Furthermore, the OSC is particularly sensitive to resales in Ontario of securities of non-reporting issuers distributed without a prospectus. See Nim E Company, 9 ONT. SEC. Commission Bull. 2027 (1986).

57. Securities Act, 8 Ont. Rev. Stat. ch. 466, § 73(1) (1980). 
and income tax laws are not barriers to Canadian participation in the attractive U.S. securities market. Because of the relative sizes of the securities markets, Canadian issuers are more likely to make trans-border equity offerings in Europe and the United States than U.S. issuers would be to make such offerings in Canada. The constraints imposed by Canadian domestic ownership legislation are not burdensome to multinational equity offerings by Canadian issuers. Under the Investment Canada Act, ${ }^{58}$ the 1985 successor to the much maligned Foreign Investment Review Act, the acquisition of control of a Canadian business with assets of $\$ 5,000,000$ or more by non-Canadians is a reviewable transaction. ${ }^{59}$ For purposes of the Investment Canada Act, an entity is deemed to be Canadian controlled if Canadians own a majority of its voting shares, unless it is established that the entity is in fact controlled by a non-Canadian or by a voting group controlled by non-Canadians. ${ }^{60}$

On the income tax side, the greatest difficulty for the issuer in having nonCanadian shareholders is the withholding tax on dividends or interest which, by virtue of the Canada-United States Tax Convention, is not greater than $15 \%$ in the case of dividends or interest paid to U.S. residents. ${ }^{61}$ Furthermore, interest paid on certain long-term obligations by a Canadian corporation to a non-resident dealing at arm's length may be paid free of withholding tax. ${ }^{62}$

\section{B. The SEC's Proposed Approaches to Multinational Securities Offerings}

The SEC's 1933 Act Release requested comment on the desirability of facilitating multinational offerings by alternative approaches. The common prospectus approach requires the "development of a common prospectus which would be simultaneously filed with each of the country's respective securities administrators."63 The reciprocal approach is an "agreement by the three countries that a prospectus accepted in an issuer's domicile which meets certain standards would be accepted for offerings in each of the participating countries." 64 The jurisdictions contemplated by the 1933 Act Release were the United States, the United Kingdom, and Canada.

Many commentators have observed that, in theory, the common prospectus is the better approach. Yet, most commentators also despair of achieving agreement by all of the regulators and representatives of the

58. Ch. 20, 1985 Can. Stat. \& 14.

59. Id. $\S 14(3)$. Where the acquisition of control occurs not directly by way of acquisition of the assets or shares of the Canadian business but rather indirectly by way of acquisition of the shares of a non-Canadian corporation, in most cases the transaction will not be reviewable unless the assets of the entity carrying on the business in Canada have a value of at least $\$ 50,000,000$. Id. $\$ \S 14(1)$, 14(4), 28.

60. Id. § 26.

61. Income Tax Act, ch. 63, 1970-1972 Can. Stat. \& 212(2), as amended; Tax Convention and Proposed Protocols with Canada, art. 10, § 2, Sept. 26, 1980, reviewed in: Senate Comm. on Foreign Relations, Tax Conventions and Proposed Protocals with Canada, S. Exec. Doc. No. 22, 98th Cong., 2d Sess. 1, 25 (1984).

62. Income Tax Act, ch. 63, 1970-1972 Can. Stat. \& 212(1)(b)(vii), as amended.

63. 1933 Act Release, supra note 1 , at 9281 .

64. Id. at 9281 . 
regulatees concerning the contents of a common prospectus. Notwithstanding these difficulties with the common prospectus approach, the reciprocal approach may be found objectionable because it would tend to undermine the prospectus system as applied by each jurisdiction to its domestic issuers. ${ }^{65}$ If reciprocity meant less detail in prospectuses for multinational offerings, then what would be the justification for requiring more detail in domestic offerings? One answer may be the size of the issuer. The ABA Corporate Law Section's proposal for a reciprocal approach would limit eligibility to "world class" issuers. 66

\section{Reciprocity Plus Supplementation}

We are likely headed (if anywhere) toward the type of system suggested by the ABA Corporate Law Section. This body recommends reciprocal acceptance of a prospectus qualified in the issuer's home jurisdiction plus supplementation in accordance with the domestic standards of each participating jurisdiction in a few key areas, notably accounting matters and management's discussion and analysis of operating results. ${ }^{67}$

If multinational meant Canada and the United States, reconciliation of prospectus requirements would be a non-issue. Prospectuses in the two countries are virtually identical apart from differences in the management discussion and analysis section, accounting principles, and the fact that in U.S. prospectuses audited statements of income and changes in financial position are required for only three years whereas in Canada they generally are required to cover five years. ${ }^{68}$ The management discussion in a U.S. prospectus tends to be more detailed, although not necessarily more informative, than in a Canadian prospectus. Many requirements of Regulation S-K that are not specifically included in Canadian regulations are nonetheless disclosed in Canadian prospectuses, simply as "other material facts." 69 This similarity of prospectuses, as drafted, may be due in some measure to the similarity in statutory standards of liability in the two countries. Canadian securities lawyers are quite familiar with Bar Chris and its teachings on the subject of due diligence. ${ }^{70}$ While making an offering in the United States entails for a Canadian issuer additional printing costs and fees for lawyers and accountants, the burden of these increased costs would be far from overwhelming, especially where the issuer and the issue are large.

65. Letter of submissions from Clarkson Gordon to the Securities and Exchange Commission Concerning Multinational Securities Offerings 3 (July 10, 1985).

66. Letter of submissions from the American Bar Association, Section of Corporation, Banking and Business Law, to the Securities and Exchange Commission Concerning Multinational Securities Offerings 8 (July 15,1985 ).

67. Id. at 6-8.

68. Compare SEC Regulation S-X, Rule 3-02(a), 17 C.F.R. 210.3-02(a) (1986) with Regulation 910, ONt. Rev. Regs. \& 4191 (a) (1980).

69. SEC, Staff Survey of the Disclosure Requirements of the United States, the United Kingdom and the Canadian Provinces of Quebec, Ontario and British Columbia (Feb. 1985) (available in the office of Law and Contemporary Problems).

70. Escott v. Bar Chris Constr. Corp., 283 F. Supp. 643 (S.D.N.Y. 1968). 
The differences in generally accepted accounting principles as between the United States and Canada are numerous. Depending on the financial situation of the issuer, these differences can be highly material. For example, in Canada, certain development costs can be capitalized that in the United States must be expensed. Foreign currency gains and losses on long-term debt must be recognized on an annual basis in the United States; in Canada, they must be computed annually but the resulting gain or loss is amortized over the remaining life of the debt. There are various differences in pension plan accounting, including, for example, the recapturing of funds from an over-funded pension plan. Canadian principles allow the entire amount to be recognized as an extraordinary income item in the year of recapture. In contrast, U.S. principles require that the income be recognized over a period of not less than 10 years. Interest costs associated with long-term construction and inventories must be capitalized in the United States and must be expensed in Canada. The test for extraordinary items is, in certain cases, more restrictive in the United States than in Canada. Canadian accounting principles include preferred shares redeemable at the option of the holder in shareholders' equity; they are excluded in the United States. Finally, there are differences in the accounting treatment for shares issued pursuant to employee stock option and stock purchase plans.

The OSC staff submission in response to the 1933 Act Release suggested dispensing with the requirement of accounting reconciliation in multinational prospectuses. ${ }^{71}$ This proposal does not appear acceptable because it would impede investors and analysts from meaningfully comparing financial performance of a foreign issuer with that of a domestic issuer in the same industry. Doubtless, the reconciliation requirements add substantial expense to the auditors' fees incurred in a public offering and also burden the issuer by requiring additional financial records to permit such reconciliation. Cost savings, however, are not everything; reconciliation is a requirement that must be preserved in the interest of comparability.

As others have noted, ${ }^{72}$ a reciprocal prospectus system that would result in disclosure in one jurisdiction but not in another is completely impracticable because of the liabilities for failure to disclose imposed by section 11 of the 1933 Act and section 126 of the Ontario Securities Act. Faced with such potential liabilities and the possibility that a matter disclosed in one jurisdiction would be found material by a court in a jurisdiction where it was not disclosed, a common prospectus containing the disclosures mandated by the most demanding jurisdiction will prevail in multinational offerings. The prospectus standards of both Canada and the United States require not simply compliance with the items set out in the applicable form and regulations but also that the document contain full, true, and plain disclosure

71. See OSC Response to 1933 Act Release, supra note 11, at 3987-88.

72. Letter of submissions by the Association of the Bar of the City of New York to the Securities and Exchange Commission Concerning Multinational Securities Offerings 2 (May 21, 1985). 
of all material facts without omitting any facts necessary to prevent the statements made from being misleading. ${ }^{73}$

\section{Remaining Obstacles to Internationalization}

Although the harmonization of prospectus contents is generally not much of a problem for Canadian issuers, there are a number of real disincentives to Canadians seeking to issue securities in the United States. It is unclear, however, if solutions to any or all of these disincentives do or should exist. These disincentives include differing standards for entitlement to use a short form prospectus, differing continuous disclosure obligations, and differing standards and procedures governing civil liability. ${ }^{74}$

The short form prospectus offers advantages to the issuer in terms of its cost of preparation and speed of clearance. In Canada, issuers which have outstanding shares (not including preferred shares) with an aggregate market value of at least $\$ 75,000,000(\mathrm{Cdn}$.) held by non-insiders may use a short form prospectus, incorporating continuous disclosure documents by reference. To qualify for the use of a short form prospectus the issuer must: (1) file an annual information form ("AIF"), which is a document similar to a Form 10$\mathrm{K}$; (2) be a reporting issuer for a period of thirty-six months prior to filing the AIF; and (3) not be in default of any of its obligations as a reporting issuer when the preliminary short form prospectus is filed or when the receipt is issued for the final prospectus. ${ }^{75}$ Reporting issuers are, principally, those that have filed a prospectus or have a class of securities listed on an exchange. ${ }^{76}$ The principal obligations of reporting issuers are to provide annual and quarterly financial statements, solicit proxies, and promptly disclose all material changes in their affairs. ${ }^{77}$ The timely disclosure obligation in section 74 of the Ontario Securities Act is actually more demanding than the Form 8$\mathrm{K}$ requirement under the $1934 \mathrm{Act} ;{ }^{78}$ the former covers all material changes and not just a specified list and the report is required "as soon as practicable" but in no event more than ten days after the date of the change.

The rules under the 1933 Act for use of the short form prospectus involve a substantially higher size requirement (for equity offerings at least $\$ 100,000,000$ (U.S.) in market value of shares held by non-affiliates) ${ }^{79}$ than the Canadian rules. The U.S. short form prospectus incorporates by

73. Securities Act, 8 Ont. Rev. Stat. ch. 466 , §§ 1(1)24, 58(1) (1980); Securities Act of 1933, 15 U.S.C. $\& 11(1982)$.

74. For a discussion of differing standards for entitlement to use a short form prospectus, see infra notes 75-82 and accompanying text. For a discussion of differing continuous disclosure obligations, see infra notes 83-85 and accompanying text. For a discussion of differing civil liability provisions, see infra notes $86-91$ and accompanying text.

75. See OSC Policies § 5.6, 3 Can. Sec. L. Rep. (CCH) ף 471-506 (1987).

76. Securities Act, 8 ONT. Rev. Stat. ch. 466, § 1 (1)38 (1980).

77. Id. at $\S \S 74,76,77,84,85$.

78. Form 8-K is reprinted at 4 Fed. Sec. L. Rep. (CCH) \31,001 (July 1, 1985).

79. Instructions to Form S-3 under the 1933 Act. The form is reprinted at 2 Fed. Sec. L. Rep. (CCH) I 7,152 (Apr. 22, 1983). If the annual trading volume is less than $3,000,000$ shares, then the market value figure rises to $\$ 150,000,000$. For offerings of debt and preferred shares, in lieu of the size requirement the critical factor is the rating of the security. 
reference either the Form 10-K or the Form 20-F, both of which require more detail than the Canadian AIF. For most foreign private issuers, the requirement relating to minimum market value of outstanding securities will be $\$ 300,000,000$ (U.S.) rather than $\$ 100,000,000$ (U.S.). The lower figure applies only to foreign private issuers who report to the SEC on Form 10-K, and the higher figure applies to foreign private issuers who report on Form 20-F. 80

Several hundred Canadian issuers are qualified in terms of size and status as a reporting issuer to use the Canadian short form prospectus and over one hundred of these issuers are actually eligible to use it by virtue of having a current AIF on file. However, only a handful of Canadian issuers would meet the size requirement of Form F-3 under the 1933 Act. Therefore, with rare exceptions $^{81}$ a Canadian issuer must forego the possibility of using a short form prospectus if it wishes to qualify shares for sale in the United States.

Continuous disclosure obligations impose important disincentives on Canadian issuers proposing multinational securities offerings in the United States. Canadian issuers become subject to the full range of continuous disclosure obligations under the 1934 Act when they file a registration statement under the 1933 Act. ${ }^{82}$ Even if the issuer is already subject to certain 1934 Act reporting requirements (for example, by virtue of seeking a NASDAQ quotation), because of a perverse compliment paid only to Canadians among all foreign issuers, the issuer will no longer be able to use the Form 20-F and will have to use the Form 10-K for annual reports. The issuer will also lose the other advantages mentioned earlier in this article which are associated with use of Form 20-F. ${ }^{83}$ This issuer will have to comply with the normal rules under the 1934 Act relating to proxy solicitation, quarterly reports, and reports of current changes on Form 8-K, and its insiders will become subject to insider trading reporting pursuant to section 16(a) and recovery of short-swing profits under section 16(b) of the 1934 Act. Apart from section 16(b), which is regarded simply as bizarre by Canadians and by others outside the United States, these various continuous disclosure obligations cover familiar territory. But the U.S. obligations are generally more detailed, and therefore more burdensome to comply with, than their Canadian counterparts. Canadian information circulars (proxy statements) are not reviewed by the securities commissions; and interim reports to shareholders generally consist of an unaudited income statement, a statement of changes in financial position, and a reasonably short and non-specific cover

80. Compare Form S-3, Instruction I(A)(5), 2 Fed. Sec. L. Rep. (CCH) 7,152 (Apr. 22, 1983) with Form F-3, Instruction I(A)(4), 2 Fed. Sec. L. Rep. (CCH) \ 6,971 (Dec. 4, 1982).

81. One exception is Alcan Aluminum Limited, which made its 1983 multinational offering using a short form prospectus both in Canada and the United States.

82. This is the case because such an issuer will, by virtue of filing the 1933 Act registration statement, become subject to section 15 (d) of the $1934 \mathrm{Act}$ and, thereby, ineligible to use Form 20-F. See 17 C.F.R. $\$ 249.220$ f (1986).

83. See supra notes 21-25 and accompanying text. 
letter from the president. Generally, they do not go into the depth of detail required, for example, by Item 303 of Regulation S-K. ${ }^{84}$

Exposure to civil liability is perhaps the most fundamental decision facing Canadian corporations which plan to issue securities or develop a secondary market in the United States. There does not exist in Canada the broad statutory and quasi-statutory rules of securities law civil liability (in regard to secondary market transactions) found in the U.S. federal securities laws. Also, the Canadian litigation culture is not as hospitable to plaintiffs as that of the United States.

Ontario, Nova Scotia, Quebec, Alberta, and British Columbia each have civil liability provisions for misleading prospectuses closely modelled after section 11 of the 1933 Act. ${ }^{85}$ These four provinces also have liability provisions relating to take-over bid circulars analogous to those for prospectuses, ${ }^{86}$ but they have neither express liability provisions similar to section 17 (a) of the 1933 Act nor implied liabilities similar to those deriving from section 10(b) or 14(e) of the 1934 Act $^{87}$ In 1984, the OSC published draft amendments to the Ontario Securities Act that would impose upon issuers civil liability for continuous disclosure documents, ${ }^{88}$ but these proposals have dropped from view.

The extent to which liabilities under the U.S. federal securities laws are broader than those flowing from the common law tort of deceit is debatable (and beyond the scope of this article). Even after ten years of restrictive United States Supreme Court interpretations of the reach of the anti-fraud provisions, common law remedies are probably less available than implied statutory remedies only because at least a semblance of privity is required for the former. Whether as cause or effect, Canadian rules on contingent fees, costs, and class actions reflect the relative non-litigiousness of Canadians as compared with Americans. In Ontario, contingent and percentage based fees in litigation are unlawful. ${ }^{89}$ The losing party in litigation is usually ordered to pay the winning parties' costs, including counsel fees. However, counsel fees are awarded according to a schedule which does not place upon the losing party the entire burden for the winning party's fees unless the losing party's position was particularly baseless. Finally, in practice, damage claims may not

84. 17 C.F.R. \$229.303 (1986). This is the item entitled "Management's Discussion and Analysis of Financial Condition and Results of Operations."

85. See Securities Act, 8 ONT. Rev. Stat. ch. 466 \$ 126 (1980); Securities Act, ch. 11, 1984, N.S. Stat. \$ 117; Securities Act, ch. 48, 1982 Que. Stat. \$\$ 217-220; Securities Act, ch. 5-6.1, 1981; Alta. Stat. \$ 168; Securities Act, ch. 42, 1987. B.C. Stat. \$114. An important difference, however, is that the Canadian provisions appear to place upon the plaintiff the burden of proving a defendant's lack of due diligence. Placing this burden on the plaintiff seems an odd policy choice because the defendant is more likely to be in possession of the facts relating to diligence.

86. Securities Act, 8 Ont. Rev. Stat. ch. 466, \& 127 (1980); Securities Act, ch. 48, 1982; Que. Stat. §§ 223-225.1; Securities Act, ch. S-6.1, 1981; Alta. Stat. § 169; Securities Act, ch. 42, 1987; B.C. Stat. $\$ 115$.

87. 15 U.S.C. $\S \S 78 \mathrm{j}(\mathrm{b}), \mathrm{n}(\mathrm{e})(1982)$.

88. Ont. Sec. Commission Bull. 4909 (1984).

89. Solicitors Act, 8 Ont. Rev. Stat. ch. $478, \$ 30$ (1980). The prohibition on contingent fees in litigation is not universal in Canada. Manitoba, for example, permits such fee arrangements. 
be prosecuted in Canada by way of class action. ${ }^{90}$ The preceding catalogue simply suggests that the real disincentive to a Canadian issuer in making a multinational securities offering in the United States is not the difficulties in prospectus qualification but rather a hesitancy to undertake the burdens of SEC-style continuous disclosure and the perceived risk of enormous civil liabilities.

The possible application of Canadian "blocking legislation" to the enforcement of U.S. securities laws against Canadian entities has caused some concern in the United States. ${ }^{91}$ Under the Foreign Extraterritorial Measures Act (the "FEMA"), ${ }^{92}$ production of information requested by a foreign tribunal may be prohibited when the Attorney General of Canada determines that production is likely to affect adversely significant Canadian interests in relation to international trade or commerce or is otherwise likely to infringe Canadian sovereignty. The FEMA was enacted in response to extraterritorial application of U.S. antitrust laws and the Trading With the Enemy Act, ${ }^{93}$ both areas of substantive law where the Canadian policy is quite different from U.S. antitrust and national security laws and policies. Nevertheless, because Canadian and U.S. securities law enforcement policies are very similar, it is unlikely that the Canadian Attorney General would invoke the FEMA, especially where the subject matter involves a Canadian company that had deliberately chosen to participate in the U.S. securities market. Canadian blocking legislation in the securities law enforcement context appears to pose no real problem.

\section{VI}

\section{Conclusion}

Although the SEC's release on multinational securities offerings has proved thought provoking and has generated much paper, from a Canadian perspective it appears to fall somewhat wide of the mark. While a common prospectus or a reciprocal prospectus approach to multinational offerings, if developed, might facilitate or increase the frequency of multinational offerings, Canada is unlikely to soon become a major market for nonCanadian securities.

On the export side, Canadian issuers do not experience major difficulties in complying with U.S. prospectus rules, apart possibly from the accounting

90. The difficulty is that, while most of the provinces have in their rules of civil procedure provisions authorizing class actions, they require that class members have "the same interest" in the subject matter of the litigation and the courts have held the requisite sameness to be lacking where the claims for damages (assuming that the class is the plaintiff) all depend upon the claimant's individual transactions with the defendant. See General Motors of Can., Ltd. v. Naken (1983) 1 S.C.R. $72,79-80$.

91. See the exchange of correspondence between the Securities and Exchange Commission and the Ontario Securities Commission regarding a trading link between the American Stock Exchange, and the Toronto Stock Exchange, published in 8 Ont. Sec. Commission Butl. 4879 (1985).

92. Ch. 49, 1984 Can. Stat. \& 3. See also Business Records Protection Act, 1 Ont. Rev. Stat. ch. $56(1980)$

93. 50 U.S.C. \$ I (1982). 
area. Absent the development of a generally accepted set of accounting standards on a supra-national basis, it is hard to see how that difficulty could be ameliorated. Many Canadian issuers have caused their shares to be listed on U.S. securities exchanges or to be quoted on the NASDAQ system. After taking such steps, issuers may be compelled as a practical matter to qualify further public distributions of the listed or quoted class of securities for sale in the United States unless they can devise satisfactory procedures to make sure that the newly issued securities do not find their way into the hands of U.S. purchasers during or within a short time following the distribution. Canadian issuers are also active in the Euromarket, but disclosure standards in that market are, if anything, less demanding than in North America.

While internationalization may be upon us, it is doubtful that its development has been influenced much by different standards of prospectus disclosure or would be influenced much by the development of more uniform standards. A more pressing concern for Canada may be the danger to the depth and liquidity of the Canadian securities markets resulting from the development outside the country, especially in London, of major trading markets for Canadian securities. 
